\title{
PENGARUH SENAM HIPERTENSI LANSIA TERHADAP PENURUNAN TEKANAN DARAH LANSIA DENGAN HIPERTENSI DI PANTI WREDA DARMA BHAKTI KELURAHAN PAJANG SURAKARTA
}

\author{
Totok Hernawan ${ }^{1}$, Fahrun Nur Rosyid ${ }^{2}$ \\ ${ }^{1,2}$ Program Studi Keperawatan Fakultas Ilmu Kesehatan Universitas Muhammadiyah \\ Surakarta. Jl. A. Yani, Pabelan, Kartasura, Surakarta. \\ Email: ${ }^{1}$ totok.hernawan@gmail.com, ${ }^{2}$ fnr100@ums.ac.id
}

\begin{abstract}
ABSTRAK
Masalah kesehatan yang terjadi pada lansia umumnya adalah penurunan fungsi organ yang memicu terjadinya berbagai penyakit degeneratif termasuk hipertensi. Penyakit degeneratif pada lansia jika tidak ditangani dengan baik maka menurunkan kualitas hidup lansia. Hipertensi merupakan suatu gejala penyakit degeneratif kardiovaskuler yang paling banyak di alami oleh lansia dan belum dapat diketahui dengan pasti penyebabnya. Penatalaksanaan hipertensi pada lansia selain dengan farmakologi dapat pula dilakukan dengan non farmakologi seperti senam hipertensi. Penelitian ini bertujuan untuk mengetahui pengaruh senam hipertensi lansia terhadap penurunan tekanan darah lansia dengan hipertensi di Panti Wredha Darma Bhakti Kelurahan Pajang Surakarta. Penelitian ini adalah penelitian kuantitatif dengan rancangan preexperiment design One Group Pre test-post test. Pengumpulan data menggunakan Sphygmomanometer air raksa, sedangkan analisis data menggunakan uji Wilcoxon Signed Rank Test. Hasil dari penelitian ini adalah tekanan darah sebelum pemberian intervensi sebagian besar adalah prehypertension (39\%), tekanan darah setelah pemberian intervensi senam hipertensi sebagian besar adalah normal (56\%), danterdapat pengaruh senam hipertensi terhadap tekanan darah lansia di Panti Wredha Dharma Bhakti Pajang Surakarta $(p$-value $=0,001)$.
\end{abstract}

Kata kunci: Lansia, senam hipertensi, tekanan darah

\begin{abstract}
Health problems that occur in the elderly generally are the decline in organ function that triggers the occurrence of various degenerative diseases including hypertension. Degenerative disease in elderly if not handled properly hence decrease the quality of life of elderly. Hypertension is a symptom of the cardiovascular degenerative disease that has not been known the cause, which many experienced by the elderly. Management of hypertension in the elderly in addition to pharmacology can also be done with non-pharmacology such as hypertension gymnastics. The purpose of the study was to determine the influence of elderly hypertensive gymnastics on decreased blood pressure elderly with hypertension in Panti Wredha Darma Bhakti Pajang, Surakarta. This research was a quantitative research with the
\end{abstract}


pre-experiment design with One Group Pretest-posttest. Data collection using mercury sphygmomanometer, while data analysis using Wilcoxon Signed Rank Test. The results revealed that the blood pressure before the intervention was mostly prehypertension (39\%), while the blood pressure after hypertensive gymnastics intervention was largely normal (56\%). There was the influence of hypertensive gymnastics to elderly blood pressure in Panti Wredha Dharma Bhakti Pajang Surakarta $(\mathrm{p}$-value $=0.001)$.

Keywords: Elderly, hypertension gymnastic, blood pressure

\section{PENDAHULUAN}

Meningkatnya penduduk lanjut usia dibutuhkan perhatian dari semua pihak dalam mengantisipasi berbagai permasalahan yang ada. Penuaan penduduk membawa berbagai implikasi baik dari aspek social, ekonomi, hukum, politik dan terutama kesehatan (Komnas Lansia 2010).

Meningkatnya populasi lansia ini tidak dapat dipisahkan dari masalah kesehatan yang terjadi pada lansia, menurunnya fungsi organ memicu terjadinya berbagai penyakit degeneratif (Azizah, 2011). Penyakit degeneratif pada lansia ini jika tidak ditangani dengan baik maka akan menambah beban finansial negara yang tidak sedikit dan akan menurunkan kualitas hidup lansia karena meningkatkan angka morbiditas bahkan dapat menyebabkan kematian (Depkes, 2013). Beberapa penyakit degeneratif yang paling banyak diderita oleh lansia antara lain, gangguan sendi, hipertensi, katarak, stroke, gangguan mental emosional, penyakit jantung dan diabetes melitus (Riskesdas, 2013).

Prevalensi hipertensi di dunia diperkirakan sebesar 1 milyar jiwa dan hampir 7,1 juta kematian setiap tahunnya akibat hipertensi, atau sekitar $13 \%$ dari total kematian (Gusmira, 2012). Prevalensi hipertensi di Indonesia untuk penduduk berumur diatas 25 tahun adalah $8,3 \%$, dengan prevalensi laki-laki sebesar $12,2 \%$ dan perempuan $15,5 \%$.
Berdasarkan hasil Riset Kesehatan Dasar Depkes (Riskesdas) 2013, sekitar 76\% kasus hipertensi di masyarakat belum terdiagnosis. Hal ini terlihat dari hasil pengukuran tekanan darah pada usia 18 tahun ke atas ditemukan prevalensi hipertensi di Indonesia sebesar 31,7\% (Depkes RI, 2013). Hipertensi seringkali ditemukan pada lansia. Dari hasil studi tentang kondisi sosial ekonomi dan kesehatan lanjut usia yang dilaksanakan Komnas Lansia di 10 Provinsi tahun 2012, diketahui bahwa penyakit terbanyak yang diderita lansia adalah penyakit sendi $(52,3 \%)$ dan Hipertensi $(38,8 \%)$, penyakit tersebut merupakan penyebab utama disabilitas pada lansia (Kemenkes RI, 2013).

Olahraga seperti senam hipertensi mampu mendorong jantung bekerja secara optimal, dimana olahraga mampu meningkatkan kebutuhan energi oleh sel, jaringan dan organ tubuh, dimana akibatnya dapat meningkatkan aliran balik vena sehingga menyebabkan volume sekuncup yang akan langsung meningkatkan curah jantung sehingga menyebabkan tekanan darah arteri meningkat, setelah tekanan darah arteri meningkat akan terlebih dahulu, dampak dari fase ini mampu menurunkan aktivitas pernafasan dan otot rangka yang menyebabkan aktivitas saraf simpatis menurun, setelah itu akan menyebabkan kecepatan denyut jantung menurun, volume sekuncup menurun, vasodilatasi arteriol vena, karena menurunan ini 
mengakibatkan penurunan curah jantung dan penurunan resistensi perifer total, sehingga terjadinya penurunan tekanan darah (Sherwood, 2005).

Hubungan senam hipertensi terhadap pengendalian tekanan darah lansia sebagaimana disimpulkan dalam penelitian Wahyuni (2015). Penelitian menunjukkan terjadinya perbaikan tekanan darah pada lansia namun tidak mencapai taraf signifikansi yang diinginkan. Tidak tercapinya perbaikan tekanan darah yang diinginkan disebabkan adanya faktor perancu yang berhubungan dengan tekanan darah lansia antara lain pola makan, stress, aktivitas fisik, genetik serta farmakologi dalam penelitian yang tidak dapat dikendalikan.

Senam hipertensi merupakan olah raga yang salah satunya bertujuan untuk meningkatkan aliran darah dan pasokan oksigen kedalam otot-otot dan rangka yang aktif khususnya terhadap otot jantung. Mahardani (2010) mengatakan dengan senam atau berolah raga kebutuhan oksigen dalam sel akan meningkat untuk proses pembentukan energi, sehingga terjadi peningkatan denyut jantung, sehingga curah jantung dan isi sekuncup bertambah. Dengan demikian tekanan darah akan meningkat. Setelah berisitirahat pembuluh darah akan berdilatasi atau meregang, dan aliran darah akan turun sementara waktu, sekitar 30-120 menit kemudian akan kembali pada tekanan darah sebelum senam. Jika melakukan olahraga secara rutin dan terus menerus, maka penurunan tekanan darah akan berlangsung lebih lama dan pembuluh darah akan lebih elastis. Mekanisnme penurunan tekanan darah setelah berolah raga adalah karena olahraga dapat merilekskan pembuluhpembuluh darah. Sehingga dengan melebarnya pembuluh darah tekanan darah akan turun.

Hasil studi pendahuluan yang telah di lakukan oleh peneliti pada tanggal 7
Oktober 2016 di Panti Wredha Darma Bhakti Pajang Surakarta, didapatkan hasil jumlah penduduk lansia yang tinggal di panti tersebut ada 78 lansia. Catatan hasil pemeriksaan rutin dari panti menujukan dari jumlah keseluruhan lansia yang tinggal di panti, diantaranya 20 lansia termasuk hipertensi ringan, 15 lansia termasuk hipertensi sedang, 10 lansia hipertensi berat dan sisanya normotensi atau tekanan darah normal. Upaya yang dilakukan petugas Panti Wredha Darma Bhakti Pajang Surakarta dalam menangani masalah ini adalah memberikan obat anti hipertensi dan senam lansia pada umumnya, sedangkan kemampuan gerak atau mobilitas lansia terbatas tidak sesuai kalau gerakan senam yang dilakukan adalah senam lansia secara umum perlu gerakan gerakan senam yang disesuaikan dengan kemampuan gerak lansia yaitu pada senam hipertensi. Sedangkan selanjutnya pemakaian obat antihipertensi dalam jangka panjang dapat mengakibatkan ketergantungan akan obat, penurunan metabolisme pada lansia, penurunan fungsi ginjal, penurunan kemampuan jantung dan pembuluh darah, menyebabkan kerusakan fungsi kognitif yang tidak baik bagi kesehatan lansia.

Berdasarkan uraian diatas, proses penuaan atau lanjut usia merupakan suatu hal yang alamiah dan tidak dapat dihentikan. Menurut data yang diperoleh jumlah lanjut usia serta angka harapan hidup mengalami peningkatan yang cukup signifikan setiap tahun nya. Untuk mencegah penurunan fungsional tubuh pada lansia terutama tekanan darah tinggi dapat dilakukan dengan melakukan latihan fisik. Akan tetapi tidak semua latihan fisik sesuai dengan lansia mengingat kemampuan mobilisasi lansia terbatas. Oleh karena itu peneliti menggunakan senam hipertensi sebagai intervensi penelitian untuk menurunkan tekanan darah lansia hipertensi yang tinggal di Panti Wredha Kelurahan Pajang 
Kabupaten Surakarta, sehingga peneliti tertarik untuk melakukan penelitian dengan judul, "Pengaruh senam hipertensi terhadap penurunan tekanan darah lansia dengan hipertensi di Panti Wredha Kelurahan Pajang Surakarta".

\section{METODE PENELITIAN}

Penelitian ini adalah penelitian kuantitatif dengan rancangan pre experiment design One Group Pre testpost test dimana pada desain ini peneliti membandingkan nilai pre test yaitu sebelum dilakukan intevensi dan nilai post test yaitu setelah dilakukan intervensi. Populasi penelitian adalah seluruh lansia yang tinggal di Panti Wredha Kelurahan Pajang Surakarta berjumlah 82 orang dan sample sebanyak 28 lansia yang mengalami hipertensi dengan teknik sampling jenuh. Senam hipertensi merupakan aktifitas fisik yang dilakukan berupa gerakan senam khusus penderita hipertensi yang dilakukan selama 30 menit dengan tahapan 5 menit latihan pemanasan, 20 menit gerakan peralihan dan 5 menit gerakan pendinginan dengan prekuensi 4 kali dalam 2 minggu. Senam ini bertujuan untuk melestarikan peredaran darah dan meregangkan otot kaku pada lansia hipertensi. Pengumpulan data menggunakan Sphygmomanometer terkalibrasi, sedangkan analisis data menggunakan uji Wilcoxon Signed Rank Test.

\section{HASIL DAN PEMBAHASAN}

\section{Karakteristik Responden}

Tabel 1. Karakteristik Responden

\begin{tabular}{llcc}
\hline No & Karakteristik & Frekuensi & $\begin{array}{c}\text { Persentase } \\
(\boldsymbol{\%})\end{array}$ \\
\hline 1. & Jenis kelamin & & \\
\hline & a.Laki-laki & 10 & 36 \\
& b.Perempuan & 18 & 64 \\
\hline 2. & Umur & & \\
\hline & a. $60-75$ tahun & 19 & 64 \\
& b.>75 tahun & 9 & 36 \\
\hline
\end{tabular}

\section{Tekanan Darah Lansia}

Hasil pengumpulan data tekanan darah sistol dan diastol responden diperoleh tendensi statistik sebagai berikut.

Tabel 2. Tendensi Statistik Tekanan Darah

\begin{tabular}{cccccc}
\hline \multirow{2}{*}{ No } & \multirow{2}{*}{ Nilai Statistik } & \multicolumn{2}{c}{ Pre test } & \multicolumn{2}{c}{ Post test } \\
\cline { 3 - 6 } & & Sistol & Diastole & Sistol & Diastole \\
\hline 1 & Terendah & 140,00 & 80,00 & 110,00 & 70,00 \\
2 & Tertinggi & 180,00 & 100,00 & 160,00 & 100,00 \\
3 & Rata-rata & 151,43 & 95,36 & 130,36 & 82,14 \\
4 & Median & 150,00 & 95,00 & 130,00 & 80,00 \\
5 & Standar Deviasi & 11,46 & 8,81 & 14,52 & 8,33 \\
\hline
\end{tabular}

Nilai tendensi statistik tekanan darah responden pada awal pengukuran (pre test) diperoleh rata-rata tekanan darah sistol sebesar 151,43, mmHg, tekanan terendah $140 \mathrm{mmHg}$, tertinggi 180 $\mathrm{mmHg}$, median $150 \mathrm{mmHg}$ dan standar deviasi $11,46 \mathrm{mmHg}$. Selanjutnya ratarata pre test tekanan darah diastole sebesar $95,36 \mathrm{mmHg}$, tekanan terendah $80 \mathrm{mmHg}$, tertinggi $110 \mathrm{mmHg}$, median $95 \mathrm{mmHg}$ dan standar deviasi $8,81 \mathrm{mmHg}$.
Nilai tendensi statistik tekanan darah responden pada setelah intevensi (post test) diperoleh rata-rata tekanan darah sistol sebesar 130,36, $\mathrm{mmHg}$, tekanan terendah $110 \mathrm{mmHg}$, tertinggi $160 \mathrm{mmHg}$, median $130 \mathrm{mmHg}$ dan standar deviasi $14,52 \mathrm{mmHg}$. Selanjutnya pre test tekanan darah diastole sebesar $82,14 \mathrm{mmHg}$, tekanan terendah $70 \mathrm{mmHg}$, tertinggi $100 \mathrm{mmHg}$, median $80 \mathrm{mmHg}$ dan standar deviasi $8,33 \mathrm{mmHg}$. 
Selanjutnya tekanan darah responden

JNC 7 yang ditampilkan pada Tabel 3 .

dibagi dalam empat kategori berdasarkan

Tabel 3. Kategori Tekanan Darah Responden

\begin{tabular}{clcccc}
\hline \multirow{2}{*}{ No } & \multirow{2}{*}{ Kategori } & \multicolumn{2}{c}{ Pre test } & \multicolumn{2}{c}{ Post test } \\
\cline { 3 - 6 } & & Frekuensi & \% & Frekuensi & \% \\
\hline 1 & Normal & 0 & 0 & 5 & 18 \\
2 & Prehypertension & 0 & 0 & 13 & 46 \\
3 & Stage 1 hypertension & 17 & 61 & 8 & 29 \\
4 & Stage 2 hypertension & 11 & 39 & 2 & 7 \\
\hline \multicolumn{2}{r}{ Total } & 28 & 100 & 28 & 100 \\
\hline
\end{tabular}

Distribusi frekuensi kategori tekanan darah responden menunjukkan pada pretest sebagian besar responden mengalami stage 1 hypertension sebanyak 17 responden $(61 \%)$ dan sisanya stage 2 hypertension sebanyak 11 responden (39\%). Selanjutnya distribusi frekuensi tekanan darah responden pada post test menunjukkan sebagian besar adalah prehypertension sebanyak 13 responden (46\%), stage 1 hypertension sebanyak 8 responden (29\%), normal sebanyak 5 responden (18\%) dan stage 2 hypertension sebanyak 2 responden $(7 \%)$.

\section{Pengaruh Senam Hipertensi terhadap Penurunan Tekanan Darah Lansia}

Hasil uji Wilcoxon Signed Rank Test pengaruh pemberian senam hipertensi terhadap tekanan darah lansia adalah sebagai berikut.

Tabel 4. Hasil Uji Wilcoxon Signed Rank Test

\begin{tabular}{ccccc}
\hline Tekanan & \multicolumn{2}{c}{$\overline{\mathbf{X}} \pm$ SD } & \multirow{2}{*}{-value } & \multirow{2}{*}{ Keputusan } \\
\cline { 2 - 5 } Darah & Pre & Post & & \\
\hline Sistol & $151,43 \pm 11,46$ & $130,36 \pm 14,52$ & 0,001 & $\mathrm{H}_{0}$ ditolak \\
Diastole & $95,36 \pm 8,81$ & $82,14 \pm 8,33$ & 0,001 & $\mathrm{H}_{0}$ ditolak \\
\hline
\end{tabular}

Hasil uji Wilcoxon Signed Rank Test pre test dan post test tekanan darah sistol diperoleh nilai $\mathrm{Z}$ hitung sebesar 4,370 dengan nilai signifikansi ( $p$-value) sebesar 0,001 . Nilai signifikansi uji ( $p$-value) lebih kecil dari $0,05(0,001<0,05)$ sehingga diputuskan H0 ditolak yang bermakna bahwa terdapat perbedaan yang signifikan rata-rata tekanan darah sistol pre test dan post test.

Hasil uji Wilcoxon Signed Rank Test pre test dan post test tekanan darah diastole diperoleh nilai $\mathrm{Z}$ hitung sebesar 4,311 dengan nilai signifikansi ( $p$-value) sebesar 0,001 . Nilai signifikansi uji $(p$ value) lebih kecil dari $0,05(0,001<0,05)$ sehingga diputuskan $\mathrm{H} 0$ ditolak yang bermakna bahwa terdapat perbedaan yang signifikan rata-rata tekanan darah diastole pre test dan post test.
Selanjutnya penurunan rata-rata tekanan darah sistol dan diastole pre test ke post test responden ditampilkan pada Grafik 1.

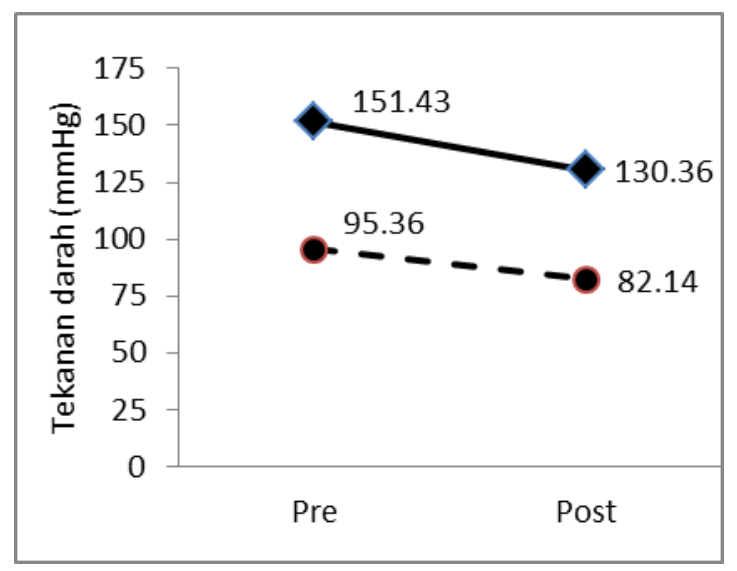

Gambar 1. Grafik Penurunan Rata-rata Tekanan darah 


\begin{abstract}
Nilai rata-rata tekanan darah sistol pre test $(151,463)$ lebih tinggi dibandingkan rata-rata tekanan darah sistol post test $(130,36)$ sehingga disimpulkan pemberian intervensi senam hipertensi berpengaruh terhadap penurunan tekanan darah sistol responden. Nilai rata-rata tekanan darah diastol pre test $(95,36)$ lebih tinggi dibandingkan rata-rata tekanan darah diastole post test $(82,14)$ sehingga disimpulkan pemberian intervensi senam hipertensi berpengaruh terhadap penurunan tekanan darah diastol responden.
\end{abstract}

\title{
DAFTAR PUSTAKA
}

Azizah., 2011, Keperawatan lanjut usia, Graha Ilmu, Yogyakarta.

Departemen Kesehatan Republik Indonesia., 2013, Profil Kesehatan Indonesia 2013, Departemen Kesehatan Republik Indonesia, Jakarta.

Gusmira, S., 2012, Evaluasi Penggunaan Antihipertensi Konvensional dan Kombinasi Konvensional Bahan Alam pada Pasien Hipertensi di Puskesmas Wilayah Depok, Makara, Kesehatan, Vol. 16, NO. 2. 77-83.

Kemenkes RI, 2013, Buletin Jendela Data dan Informasi Kesehatan, Kemenkes RI, Jakarta.

Komnas Lansia., 2010, Profil Penduduk Lanjut Usia 2009, Jakarta.

Mahardani, N.M.A.F., 2010, Pengaruh Senam Jantung Sehat terhadap Penurunan Tekanan Darah pada Penderita Hipertensi di klub Jantung Sehat Klinik Kardiovaskuler Rumah Sakit Hospital Cinere tahun 2010.

Riset Kesehatan Dasar (Riskesdas)., 2013, Kementrian Kesehatan RI, Badan Penelitian dan Pengembangan Kesehatan Kementrian Kesehatan RI, Jakarta.

Sherwood, L., 2005, Fisiologi kedokteran:dari Sel ke Sistem, EGC, Jakarta.

Wahyuni, S., 2015, Pengaruh Senam Hipertensi Terhadap Tekanan Darah ansia di Posyandu Lansia Desa Krandegan Kabupaten Wonogiri, Skripsi, Program Studi S-1 Keperawatan Stikes Kusuma Husada Surakarta, Surakarta. 